\title{
Information and communication technologies in teaching adult learners a foreign language
}

\author{
O. V. Los, N. V. Gagina \\ Chernihiv National University of Technology, Chernihiv, Ukraine \\ Corresponding author. E-mail: lena@kilko.name
}

Paper received 18.01.18; Revised 23.01.18; Accepted for publication 25.01.18.

https://doi.org/10.31174/SEND-PP2018-154VI64-08

Abstract. The article deals with the specific role of information and communication technologies in teaching adult learners a foreign language. Andragogical principles and characteristics of adult language learners are specified. Multimedia language programmes, computer games, podcasts as the most effective information and communication technologies and e-learning as a learner-focused approach are studied. The advantages of information and communication technologies for adult foreign language learners are emphasised.

Keywords: information and communication technologies, adult learners, foreign language, e-learning, multimedia programmes, podcast.

Relevance of the study. Contemporary changes in the system of adult education in Ukraine are related to the fast moving processes in the society such as globalization, technological advances, economic and social progress which provide both new opportunities for adult population of Ukraine, and the need for further training, retraining, getting a new speciality or job. To ensure some positive changes in the social and economic development of the country it is necessary to improve the system of adult education as well as to create favourable environment for its effective functioning. Information and communication technologies are recognized among all modern educational technologies as suggesting considerable possibilities for improving foreign language teaching in the system of adult education.

Analysis of recent researches and publications. Theoretical and practical issues relating to adult education are studied by O. Anischenko, L. Antsiferova, E. Holton, P. Jarvis, M. Knowles, L. Lukyanova, N. Nychkalo, O. Ohienko, R. Swonson, L. Sigayeva, A. Smith, S. Vershlovskyi, S. Zmeyov, and other scholars. The use of information technologies in adult education is actively researched by $\mathrm{O}$. Bulavenko, J. Dron, R. Hurevych, L. Jakobsen, L. Maksymova, A. Odinets, I. Pichugina, and others.

Adult education as a component of continuous lifelong learning performs the following important interrelated functions: socio-cultural, developing function which creates the environment for continual creative growth of an individual; educational, compensatory function which means improvement of the previous education, acquisition of new knowledge based on information technology achievements; adaptive function that involves flexible vocational training, retraining, improving education or changing specialism; economic function which satisfies the need for highlyqualified and competitive professionals, prepared to apply the best practices and latest technologies in their professional career [6, p. 350-351].

Objective of the study. Rethinking of the conceptual approaches to adult language teaching in the system of formal and informal education requires active implementation of innovative technologies that enable autonomous, productive, high-quality foreign language learning and fulfilment of adults' individual potential in Ukraine. The objective of the study is to analyse the most effective information technologies in teaching foreign languages to adult learners.

Presentation of the main material of the study. Most scholars conducting research in the field of adult education acknowledge that the process of adult learning has a specific character. The main distinction between a conventional pedagogical model and an andragogical model for learning is grounded on the assumptions about adult learners.
The andragogical model is based on the following principles: the need to know why to learn something, the learner's self-concept of being autonomous and self-directed, the role of the adult learners' prior experiences, readiness to learn, life-centred or task-centred orientation to learn, adults' internal motivation to learn [5, p. 65-68].

As foreign language learners, adults are goal oriented and direct their learning to fulfil particular life and professional needs, demands and expectations. They can usually communicate confidently and effectively in their first language, may code switch between several other languages and have greater cognitive and linguistic capabilities. Adult learners are able to discuss their learning styles and strategies, employ strategies to monitor and evaluate their own learning during a particular task, and they need an accepting, secure, and supportive environment that engages them [7].

All these characteristics have to be taken into account in order to design the relevant learning content that meets the specific needs of adult language learners, to create motivating, autonomous, supportive, an emotionally safe learning environment to ensure the effectiveness of learning. In our opinion information and communication technologies in education can help satisfy these demands.

It is important to note that teaching adults a foreign language by means of information and communication technologies requires task-based instruction activities; learnercentred and communicative approaches to language teaching and appropriate methods promoting learner independence, individual strategies of foreign language learning, and selfevaluation processes in the online environment; facilitation support and guidance helping learners to overcome difficulties, encouraging online communication between learners and fostering student cooperation and collaboration with each other.

One of the most rapidly developing approaches to teaching and learning in formal and informal education is elearning. In contemporary literature e-learning is defined as learner-focused approach to the use of new multimedia technologies and the Internet to improve the quality of learning by facilitating access to resources and services, as well as remote exchanges and collaboration [8, p. 5]; a blend of traditional and newer techniques and tools, encompassing the use of various technologies with flexible, accessible, and inclusive characteristics to support teaching and enhance learning [4, p. 108]; learning that takes place through and/or with the aid of Internet or network-based technologies [2,p.7].

In our opinion, e-learning can considerably contribute to adult foreign language learning as it creates opportunities for effective delivery of task-based instruction; enables increased access to authentic resources and materials of vari- 
ous formats; individualise, intensify learning and enhance student experience; increase motivation and learner autonomy; ensures flexibility of learning and appeals to adults with different learning styles.

The implementation of the e-learning system that meets individual and professional needs and takes into account andragogical principles and psychological characteristics of adults provides an opportunity to create flexible, efficient, psychologically comfortable, functional, personalized and autonomous learning environment that will ensure successful development of general and professionally-oriented communicative language competences in a foreign language [3].

A well-structured e-learning system offers adult learners a personalized and differentiated approach and opportunity to schedule individually study time, to choose their own pace, to implement individual learning trajectories, focusing on the level of language competence, individual abilities, interests and meaningful goals. It is important to note that the principle of autonomy in adult education is realized through individual planning, formulating goals, self-organizing the education process, choosing resources, methods and appropriate learning paths, taking responsibility for own learning, and evaluating learning outcomes; applying flexibly and modifying their learning strategies based on the recommendations of the tutor.

E-learning makes use of a great variety of information and communication technologies and tools like electronic textbooks, electronic trainers, multimedia software, educational programmes, games, etc.

Unlike conventional textbooks, electronic textbooks, multimedia programmes and tools make it possible to present educational material in a more visualized and informative way engaging all types of learning modalities (visual, auditory and kinaesthetic), increase information load, improve perception and provide higher level of performance and emotional involvement in foreign language learning.

Including such elements as text, graphics, animation, audio, and video, modern multimedia educational programmes create an attractive multi-sensory language context for adult foreign language learners. They are widely used to provide acquisition and practice in vocabulary and grammar as well as to develop listening, speaking, reading and writing skills.

Educational multimedia programmes usually comprise the following components: presentation of material in visual (textual, graphic or video) and sound form; a series of exercises for text comprehension, reproductive and productive language use; a database which contains grammar and vocabulary reference material; a digitized pronunciation database; a series of test assignments aimed at monitoring student progress; a feedback generator that allows to recognize and correct mistakes in both reproductive and productive exercises.

A remarkable feature of multimedia programmes is that they as an independent study tool can provide fully learner controlled environment, which is better suited for adults, and promote more reflective and deeper learning. Another great benefit of such programmes is that they may have an errorchecking tool, providing learners with help, directing them to further training or moving them to the next stage and what is more important adapting the level of difficulty according to the given responses.

Thus, properly designed foreign language multimedia programmes may have great potential in adult formal and informal education as they can provide a practical independent learning experience, make the process of learning easy and enjoyable, and facilitate effective foreign language acquisition.

Among the most popular computer-based activities used for pedagogical purposes are educational games and podcasts. The use of computer games makes foreign language learning process easier and more understandable. It contributes to a more successful mastery of the language by adult learners. Educational computer games allow to identify better the potential abilities of adult learners. The game can fulfil the exclusive role in enhancing the cognitive interest, facilitating the complex process of learning, providing conditions for the development of the creative personality of adults. In the game form, it is always possible to explain quickly and easily some new material, diversify routine, and what is the most important, to interest adult learners.

In the appropriate methodologically organized educational process, the use of podcasts as authentic materials ensures the effective presentation and practicing a new lexical and linguistic material, the development of language skills, and can be considered as an important tool in the training of prepared and improvised speech.

The didactic properties of podcasts include sound nature, interactivity, ease of use, accessibility as well as the organization of study time and space.

Merriam-Webster Dictionary defines podcast as an episodic series of digital audio or video files which a user can download and listen to. It is often available for subscription, so that new episodes are automatically downloaded via web syndication to the user's own local computer, mobile application, or portable media player. Podcasting is a technology for digital content broadcasting, representing the creation, placement and distribution over the Internet of media streams (audio or video files) that are available for listening or viewing to users.

Depending on the specific tasks, podcasts can be used in individual and group work, in the classroom and at home, in the project work and in the classroom activities. There are different kinds of podcasts relating to foreign language learning namely podcasts for practicing lexical material where the podcaster explains the meaning of a word, a phrase or an idiom and illustrates them with the examples how they function in the language; podcasts aimed at developing listening skills and podcasts with listening tasks; podcasts, designed to deliver the whole foreign language lesson. Such podcasts must be accompanied by handouts.

Podcasting has a number of advantages over traditional forms of foreign language learning. This technology allows adult learners to listen to or view educational materials anywhere and at any time, without being limited to a tutor support, and to design their own individual learning schedule in the most convenient way. Podcasts can be listened to an unlimited number of times, in whole or in parts. In general, the learners themselves can specify the most suitable learning strategies.

Podcasts increase the effectiveness of foreign language teaching in the context of individualization, systematization and intensification of the learning process. They are widely used in mobile learning, promoting development of learner autonomy, critical thinking, implementing modern educational standards, corresponding to the basic principles of the student-centered approach in foreign language teaching.

M-learning as a contemporary tendency in education is learning across multiple contexts, through social and content interactions, using personal electronic devices [1, p.4]. M- 
learning is considered as formal, self-directed and spontaneous as well as learning that is context aware and context neutral. It means that the adult learners can be supported by tutors or be self-directed so that they can have a spontaneous learning experience; learning can take place in an academic setting, or any other non-academic setting.

Having considered the basic didactic properties of podcasts and their functions, it is worth mentioning the ways of their use in foreign language teaching. Podcasts could serve as a means of presenting and transferring educational materials designed by the teacher to different categories of learners, as well as a source of authentic information for foreign language adult learners. At the same time they can be used for delivering the organizational information (announcements, schedules), for recapitulation and consolidation of previously studied material and for self-preparation.

In order to use podcasts in a foreign language classroom effectively, it is important to determine the criteria for their choice which would meet particular needs of adult learners and objectives of the training. They include the following parameters: type of multimedia (video or audio) and duration of audio or video recordings; content (coherence of the podcast to the topic of the lesson); level of complexity of linguistic material; type of enunciation (monologue, dialogue, polylogue); level of reception of the recording (background noise, speech tempo, timbre of voice, dialect peculiarities of speech, individual features); authenticity (educational or authentic podcasts); system (availability of single podcasts on different topics or a series of podcasts for the entire course); updating of materials.

Tasks based on podcasts can be divided into three main groups: language exercises (presentation, consolidation, monitoring of language skills); speech receptive and speech productive exercises.

The development of speaking skills can be facilitated by practice of recording podcasts. This approach has certain considerable advantages that help focus on the phonetics of the language, to increase adult learners motivation, to identify mistakes, to save time in the classroom, and provide the availability of materials for further use and monitoring speaking skills in dynamics.

Being an easy and effective method of foreign language teaching, the podcast technology intensifies communication of adult learners, creates positive motivation, integrating mobile technologies into the educational process.

The Internet is a huge informational and educational resource which thanks to its didactic possibilities allows to practice all foreign language skills using web materials of different level of complexity for developing reading skills, authentic audio texts for improving listening skills, practicing writing skills by means of e-mailing, commenting, etc., mastering speaking skills on forums and chats. In the process of foreign language learning the Internet can also be used for search for information, authentic and reference materials, synchronous or asynchronous communication while chatting on thematic forums, organizing and holding video conferences, online testing, conducting research and project work, creating presentations. It is important to determine for what purposes we are going to use Internet resources. We can, for example, include network materials in the content of lessons and make our learners look for information when working on projects, presentations, reports, etc.

Innovative electronic technologies extend the didactic opportunities; outline a new algorithm for language teaching; allow teachers to involve crucially new forms, methods and techniques; contribute to a more effective understanding and acquisition of difficult language material, processing much more information as compared with conventional forms of teaching.

Conclusions. Obviously, information and communication technologies support the concept of continuous lifelong learning, diversify the university curricula of foreign languages, enlarge the communicative opportunities of adult learners, their linguistic capabilities, cognition of the language as a social and cultural phenomenon, promote personal interaction, develop new professional skills. Thus, the effectiveness of information and communication technologies is determined by such didactic peculiarities as information and emotional richness; convenience of simultaneous use of a large amount of educational materials; possibility of immediate use of various online resources, reference literature, dictionaries; communicative and cognitive value of linguistic material; integration of all types of language skills based on a learner-centred approach.

\section{REFERENCES}

1. Crompton, H. (2013). A historical overview of mobile learning: Toward learner-centered education. Handbook of mobile learning. (pp. 3-14). Florence, KY : Routledge.

2. Dron, J. (2007). Control and Constraint in E-Learning: Choosing When to Choose. Hershey, PA: Idea Group Publishing.

3. Gagina, N. V., Los, O. V. (2016). The effectiveness of Electronic Learning in Foreign Language Education. Proceedings from the 7th International Scientific and Practical Conference. (pp. 94-97). Chernihiv: CNPU.

4. Jakobsen, L. A. (2009) Embedding E-Learning in Further Education. Applied e-learning and e-teaching in higher education. NY : Information Science Reference.

5. Knowles, M. S., Holton III, E. F., Swanson, R. A. (2005). The adult learner: the definitive classic in adult education and human

resource development. Burlington: Elsevier.

6. Nychkalo, N. H. (2003). Contemporary issues of the development of continuous vocational education system: national and foreign experience. Continuous vocational education: philosophy, pedagogical paradigms, forecast. (pp. 350-351). K.: Naukova dumka.

7. Smith, Ann F. V., Strong, G. (2009). Adult Language Learners: Context and Innovation (Classroom Practice Series). Alexandria, VA: TESOL Publications.

8. The use of ICT to support innovation and lifelong learning for all. (2008). Commission of the European Communities. Retrieved from http://www.europarl.europa.eu/registre/docs_autres_institutions/commission_europeenne/sec/2008/2629/COM_ SEC(2008)2629_EN.pdf

\section{Информационно-коммуникационные технологии в обучении взрослых иностранному языку}

\section{Е. В. Лось, Н. В. Гагина}

Аннотация. В статье рассматриваются особенности информационно-коммуникационных технологий в обучении взрослых иностранному языку. Определены андрагогические принципы и специфические характеристики взрослых в контексте изучения иностранного языка. Изучаются мультимедийные программы, компьютерные игры и подкасты как наиболее эффективные информационно-коммуникационные технологии, а также электронное обучение в образовании взрослых. Акцентируется внимание на преимуществах информационно-коммуникационных технологий в обучении взрослых иностранному языку.

Ключевые слова: информачионно-коммуникачионные технологии, взрослые обучаемые, иностранный язык, электронное обучение, мультимедийные программы, подкаст. 